\title{
PROFITABILITY OF CATFISH PRODUCTION IN ENUGU METROPOLIS, ENUGU STATE, NIGERIA
}

\author{
${ }^{1}$ Umaru, I. L., *2Okoh, T. C., \& ${ }^{3}$ Ishiwu, R. C. \\ ${ }^{1,2,3}$ Department of Agricultural Economics, University of Nigeria, Nsukka \\ "Corresponding Author E-mail: chinonso.okoh.pg.81039@unn.edu.ng Phone: +2348032335812
}

\begin{abstract}
The study was carried out in Enugu Metropolis, Enugu State, to investigate the profitability of catfish production. Specifically, the study described the socioeconomic characteristics of catfish farmers; estimated cost and returns of catfish production and identified constraints to catfish production in the study area. Data were collected from 120 respondents who were purposively selected in the three Local Government Areas that made up Enugu Metropolis, using questionnaires. The data were analyzed using descriptive statistics, the Gross margin model and a 3-point Likert type rating scale. The study showed that $61.7 \%$ of the respondents were males with a majority (95.0\%) below the age of 45 years. The study revealed that from every 1000 fingerlings that were stocked, 980 catfishes were harvested with an average weight of $1.5 \mathrm{~kg}$ in a period of 6 months. The catfish farmers expended an average total cost of N575,168 and made an average total revenue of $\mathrm{N1}, 176,000$. This indicates a survival rate of $98 \%$ of catfishes that was reared in the area. The gross margin analysis revealed a gross margin of N652,700.00 with a net farm income of N600,832.00 for every 1000 catfishes that were raised to maturity at $1 \mathrm{~kg}$. For every $1 \mathrm{~N}$ invested in the business, there was a return of N1.25 (RCI). The study concludes that catfish production in the study area was dominated by males in their active age who were well educated. Catfish production was very profitable in the study area. The constraints facing the farmers were the high cost of feeds, insufficient capital and poor extension services. These farmers could handle large scale production if capital is made available to them which will also allow them to make more profits and become employers of labour. The study recommends that educated unemployed youths in the area should be encouraged to go into catfish farming since the business is very profitable. Soft loans should be made available by credit agencies for the catfish farmers in the area to enable them to increase their scale of operation and the farmers should form and manage functional cooperative societies to enable them to achieve economies of scale.
\end{abstract}

Keywords: Catfish, Farmers, Production, Profitability, Productivity

LICENSE: This work by Open Journals Nigeria is licensed and published under the Creative Commons Attribution License 4.0 International License, which permits unrestricted use, distribution, and reproduction in any medium, provided this article is duly cited.

COPYRIGHT: The Author(s) completely retain the copyright of this published article.

OPEN ACCESS: The Author(s) approves that this article remains permanently online in the open access (OA) model.

QA: This Article is published in line with "COPE (Committee on Publication Ethics) and PIE (Publication Integrity \& Ethics)". 


\section{INTRODUCTION}

The importance of agriculture in the economic development of a nation cannot be overstated (Afolabi, 2017). Aquaculture is the part of agriculture that is involved in the production of fish and other aquatic organisms. This facet affords fish for people in the country, adds to foreign exchange earnings, supplies raw materials to industries and generates employment. In Nigeria, aquaculture contributed 12\% to the share of Agricultural GDP between 2000 and 2004 (Akinwumi, 2014). Fish farming presently adds 3.5\% to Nigeria's Gross national product (GNP) and responsible for $0.2 \%$ of the overall world fish supply. (CBN,2011). The overall local fish supply reduced from 562,972 metric tonnes in 1983 to 524,700 metric tonnes in the year 2003; while the supply of fish from fish farming during this period increased from 20,476 to 52,000 metric tons. Artisanal fishing gave the majority of the fished produced within the period whereas fish farming contributed between $3.64 \%$ and $9.92 \%$ of the total domestic fish production.

The annual demand for fish in Nigeria is about 1.4 million tons while domestic production is about 780,000 tons. This reveals a wide gap of more than 0.7 million tons between demand and supply and this led Nigeria to annually import fish worth about USD667 million to become the highest importer of fish in Africa (Nwiro,2012; Adekoya and Miller, 2004). Over $60 \%$ of the overall protein needs of rural people are derived from fish. In 2003, the Federal Government of Nigeria put in place the presidential initiative on fisheries and aquaculture development to arrest this importation problem and to boost fish production. This brought only minimal success. The surest way to minimizing the wide gap between the demand and the supply of fish in the country is through fish farming and culture (Amaefula et al., 2010).

According to Ike and Chuks-Okonta (2014), many of the fish farmers in Nigeria focus on catfish production which has a market value of about three times that of tilapia. Catfish is the fastest-growing fish under captivity. It can thrive in a wide range of conditions because it is hardy and can tolerate dense stockings (Ume et al., 2016). Fish farming and culture can be carried out on a small or medium-scale (Adefalu et al., 2013). Other desirable fish species that are cultured in Nigeria include the Clariid fishes (Clariasgariepinus, Heteroclariassparid, Heterobranchus spp) and Tilapia (Oreochromisniloticus, Sarotherodongalilaeus and Tilapia guinensis). Fish production practice and management could be undertaken in earthen ponds, tanks, tarpaulin ponds, run-ways, glass tanks, acrylic tanks, plastic tanks, race-ways among others (FAO Fish Stat plus, 2012). The most prevalent fish-farming practice in Nigeria is pond culture. Other forms of culture include Cage, Pen, Burrow-pits, flow-through and water recirculation systems. Fish farming practices and methods, therefore, differ by farm size. Production starts with the introduction of fish fingerlings or juveniles into a rearing compartment that permits rapid growth to enable harvest within a short time. The fish farmers have to obtain an appropriate number of young fish to meet their production targets.

Fish farming has the potential to create about 30 thousand profitable jobs and generate revenue of US\$160 million on yearly basis, which would greatly boost the Nation's economy (Federal Ministry of Agriculture and Rural Development (FMARD, 2016). According to the Nigeria Bureau of Statistics (NBS), the unemployment rate in Nigeria has increased from $8.2 \%$ in 2014 to $9.9 \%$ in 2015 (NBS, 2016).

Profit in a business is obtained when the revenue realized exceeds total expenditure. The goal of every agribusiness is to make a profit. Farm profitability is the key to fish production enterprise (Ashley-Dejo et al, 2016). There is therefore a need to find out how profitable the catfish business is to encourage the unemployed to go into it. 
In Nigeria, several studies have been conducted on fish farming which includes an economic analysis of homestead fish Production in Ogun State, Nigeria (Olawunmi et al., 2010); Economic efficiency and profitability of catfish production in Isoko Area of Delta State, Nigeria (Nkamigbo et al., 2014); resource use efficiency among small scale fish farmers in Cross River State, Nigeria (Itam et al., 2014), and Profitability analysis of catfish farming in Suleja local government area of Niger State, Nigeria (Yisa et al., 2015). But in Enugu Metropolis, where there is a high rate of unemployment with only a few catfish farmers, there are no studies on the profitability of catfish production to guide and motivate investors, especially the youths to go into this business. The objective of this study, therefore, was to bridge this gap by investigating the profitability of catfish production in Enugu Metropolis. The specific objectives were to: describe the socio-economic characteristics of catfish farmers, estimate the cost and returns of catfish production and identify the constraints militating against catfish production in the study area.

\section{METHODOLOGY}

\section{STUDY AREA}

The study was carried out in Enugu Metropolis, the capital city of Enugu State. Enugu metropolis comprises Enugu East, Enugu North and Enugu South Local Government Areas (LGAs). Enugu State lies between latitudes $5^{\circ} 56^{\prime} \mathrm{N}$ and $7^{\circ} 36^{\prime} \mathrm{N}$ and longitudes $6^{\circ} 53^{\prime} \mathrm{E}$ and $7^{\circ} 55^{\prime} \mathrm{E}$ of the Greenwich Meridian (Enugu State Agricultural Development Project, ENADEP, 2009). The State occupies a landmass of approximately $8,022.95 \mathrm{~km}^{2}$ and a population of $3,267,837$ (National Population Commission, NPC, 2006).

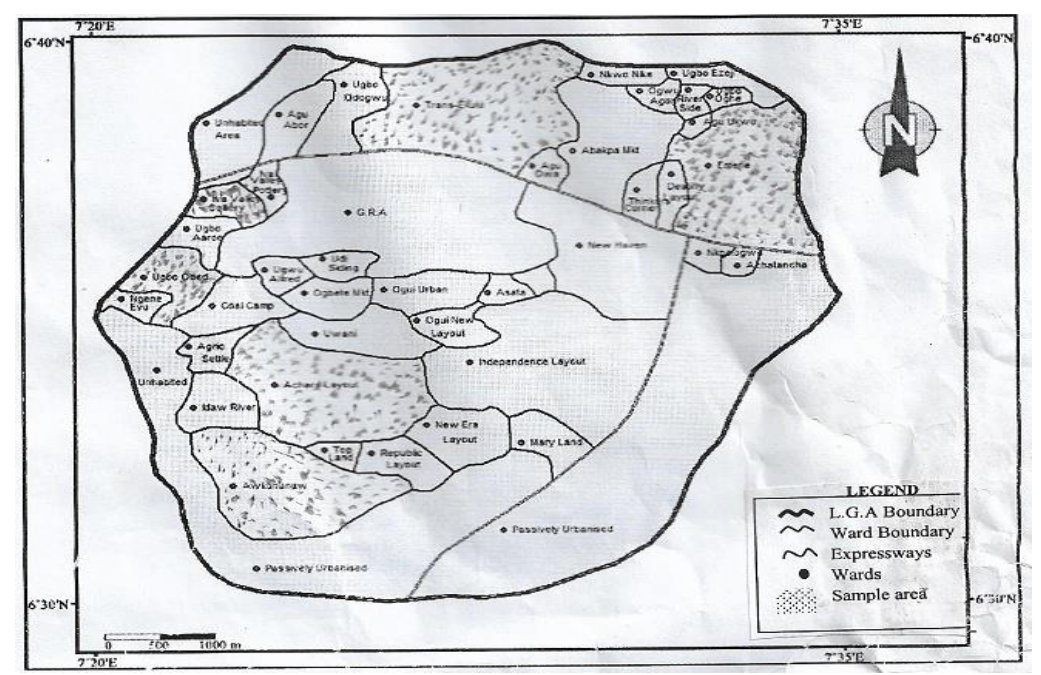

Figure 1: Map of Enugu Metropolis showing the sampled area in the three Local Government Areas;

Source: Department of Geography, University of Nigeria, Nsukka

The warmest month of the year in the area is February with an average temperature of about $29.0^{\circ} \mathrm{C}$, while the coolest month of the year is August with a mean temperature of about $24.3^{\circ} \mathrm{C}$ whereas rainfall ranges between $9 \mathrm{~mm}$ and $270 \mathrm{~mm}$ annually (Climate -data.org, CDO,2021). In the urban areas, trading is the dominant occupation, followed by 
civil service. Some major markets in the State are Ogbete main market, Afor Awkunanaw, Orie Emene and Aria market.

\section{SAMPLING PROCEDURE}

A multistage random sampling technique was used to select 120 catfish farmers in Enugu metropolis which comprises Enugu East, Enugu North and Enugu South LGAs. The first stage was the purposive selection of two towns from each of the three LGAs in the metropolis due to the high concentration of fish farms in these areas. The second and final stage involved the random selection of 20 catfish farmers from the list of farmers in each of the two towns giving a total of 120 respondents. The questionnaire captured information such as socio-economic characteristics, cost incurred and revenues obtained in catfish rearing and production constraints faced by the farmers. Descriptive statistics such as frequency distribution and percentages and gross margin techniques were used to analyze the data.

\section{MODEL SPECIFICATIONS}

(i). Gross margin analysis is expressed as:

GM =TR-TVC

Where GM = gross margin ( ()

$\mathrm{TR}=$ total revenue $(\mathrm{N})$

$\mathrm{TVC}=$ total variable cost $(\mathbb{N})$

$\mathrm{NFI}=\mathrm{GM}-\mathrm{TFC}$

$\mathrm{TFC}=$ total fixed cost

$\mathrm{RCI}=\mathrm{GM} / \mathrm{TVC}$

Where $\mathrm{RCI}=$ return on capital invested

Gross margin is the difference between TR and TVC, while Net Farm Income is GM-less TFC. Similarly, return on Investment was obtained by dividing GM with TVC. Total revenue was estimated by multiplying the average quantity of catfish sold with the average price. The fixed costs were depreciated using the straight-line method to obtain the actual value of the equipment per production cycle. The result of the difference between and depreciated TFC connotes the profitability of the business. A positive NFI depicts a profitable enterprise whereas a negative NFI signifies loss and an enterprise not suitable for continued investment of resources.

\section{THE 3-POINT LIKERT RATING SCALE TECHNIQUE}

The 3 points Likert scale rating was specified as follows: very serious (VS) $=3$; Serious (S) $=2$; and not serious (NS) $=1$. The mean score based on the 3 points Likert rating scale was computed as $3+2+1=6 / 3=2.0$ (cut off point). Any item with a mean score of 2.0 and above was regarded as a serious constraint while an item that scored less than the cutoff point of 2.0 was regarded as not a serious constraint to catfish farming in the study area.

\section{RESULTS AND DISCUSSION}

\section{SOCIO-ECONOMIC CHARACTERISTICS OF THE RESPONDENTS}

The result on the socio-economic characteristics of the respondents is presented in Table1 below. $61.7 \%$ of the 
capital investment. Women generally are burdened with family responsibilities and hardly have enough time for businesses like this. They may also not have access to capital for investment. These could have been some of the reasons only a few women were involved in the catfish production business in the Enugu metropolis. The dominance of men in fish production was also reported by Fregene et al. (2011) and Ume et al. (2016).

Table 1 also shows that $51.7 \%$ of the respondents were married. This is advantageous because members of a family can provide cheap labour for performing critical farm tasks. $48.3 \%$ were single, separated or widowed. The majority (72.5\%) were between the ages of 20-30 years, $22.5 \%$ between $32-45$ years, and $1.67 \%$ between $46-55$ years, while $3.33 \%$ were 56 years and above. This indicates that the catfish farmers were in their prime age and hence economically active. Young farmers could easily take risks which would increase output as well as income. This result agrees with the findings of Aihonsu and Olantingiri (2012) and Fregene et al. (2011).

The majority (65.83\%) of the farmers were educated having attended Universities, Polytechnics and Colleges of education as the result shows that $4.17 \%$ went through primary education, $30 \%$ obtained secondary education while $65.83 \%$ obtained tertiary education respectively. This shows that the farmers could be having high managerial skills and could take decisions objectively. The implication is that catfish farming in the study area would become more productive and successful. Fregene et al. (2011) also reported high levels of education among fish farmers in Oyo and Osun States of Nigeria.

The result of household size portrays $83.3 \%$ of the respondents as having 1-5 persons, $13.3 \%$ having $6-10$ persons while $3.3 \%$ have 11 and above. This means that the farmers could use their family members to perform some farm operations thereby reducing labour costs leading to higher income. The years of experience result shows that $17.5 \%$ of the respondents had 1-4 years of experience while the remaining $82.5 \%$ had 5 years and above experience. This indicates that the majority of the farmers have at least 5 years of experience implying that the farmers would be efficient in the use of scarce resources which increases the productivity of the catfish production in the study area. This result disagrees with the findings of (Onyekuru et al., 2019) who reported that the majority (75\%) of fish farmers had below 5 years of experience. (Oluwasola and Ige, 2015) opined that fish farming experience is a desirable for increased profitability in fish production.

Table 1: Socio-economic characteristics of catfish farmers in Enugu metropolis

\begin{tabular}{lcc}
\hline Variable & Frequency & Percent (\%) \\
\hline Okoh et al., 2021 & & OJAS 2(2) | 5
\end{tabular}




$\begin{array}{lll}\text { Male } & 74 & 61.7 \\ \text { Female } & 46 & 38.3 \\ \text { Marital status } & & \\ \text { Married } & 62 & 51.7 \\ \text { Others (Single, separated, widowed) } & 58 & 48.3 \\ & & \\ \text { Age (years) } & & 72.5 \\ 20-30 & 87 & 22.5 \\ 31-45 & 27 & 1.67 \\ 46-55 & 2 & 3.33 \\ \text { Above 55 } & 4 & \\ \text { Number of years spent in school } & & 4.17 \\ 1-6 & 5 & 30 \\ 7-13 & 36 & 65.83 \\ 14-19 & 79 & 83.3 \\ \text { Household size } & & 13.3 \\ 1-5 & 100 & 3.3 \\ 6-10 & 16 & \\ 11-15 & 4 & 17.5 \\ \text { Years of experience } & & 82.5 \\ 1-4 & 21 & \\ 5 \text { and above } & 99 & \end{array}$

\section{GROSS MARGIN ANALYSIS}

The catfish farmers incurred several costs in the course of their production. In the short run, these costs include both variable and fixed costs of production. The variable costs, involved in catfish production as shown in Table 2, include catfish seeds (fingerlings), catfish feeds, labour, petrol, transportation and miscellaneous costs (Ugwumba and Chukwuji, 2010; Ochiaka and Obasi, 2019; and Onyekuru et al., 2019).

Table 2: Average value of variable cost per 1000 catfishes per $25 \mathrm{~m}^{2}$

\begin{tabular}{ll}
\hline Variable cost & Value in (N) Per 1000 catfishes \\
\hline Feed (5-6 months) & 368,500 \\
Medication & 18,425 \\
Petrol for pumping water & 3625 \\
Fingerlings & 30,000 \\
Transportation & 16,500 \\
Utilities & 9000 \\
Miscellaneous & 17,250 \\
Total Variable cost & $\mathbf{4 6 3 , 3 0 0}$ \\
\hline
\end{tabular}

The average value of fixed cost is presented in Table 3. These are costs that last for more than one production cycle and it does not change within one production period, but can be altered in the long run. The straight- line method was used to calculate the depreciation of the equipment. The salvage value was taken to be zero since the equipment used 
depreciated and their values are taken as the fixed cost. The items include a fish pond, weighing scale, water pump, plastic tank, land, basins, $\mathrm{Ph}$ meter and net cover.

Table 3: Average value of fixed assets and their depreciation value

\begin{tabular}{llll}
\hline Fixed cost items & Total value (N) & Lifespan & Depreciation \\
\hline Land (plot) & 850,000 & 30 & 28,333 \\
pond & 45,000 & 15 & 4500 \\
weighing scale & 20,000 & 10 & 2000 \\
pumping machine & 50,000 & 15 & 5000 \\
basins/buckets & 1500 & 1 & 1500 \\
pond net cover & 2500 & 1 & 2500 \\
ph meter & 7000 & 5 & 1400 \\
plastic tank & 39,350 & 10 & 3935 \\
well digging/water & 40,500 & 15 & 2700 \\
Total Fixed Cost & & & $\mathbf{5 1 , 8 6 8}$ \\
\hline
\end{tabular}

The result of the gross margin analysis and net farm income per 1000 catfishes per $25 \mathrm{~m}^{2}$ is presented in Table 4 below. An average of 1000 fingerlings was stocked initially by the sampled fish farmers and was raised for an average period of six months. At the end of the period, 980 matured catfish were harvested and sold with each fish gaining an average weight of $1.5 \mathrm{~kg}$. This gives a total of $1470 \mathrm{~kg}$ of market sized catfish sold on average. The price of catfish in the study area varies depending on the weight gained at maturity. Those weighing $1 \mathrm{~kg}$ and above were sold at $¥ 800$ per kilogram. The analysis indicates an average TVC, TFC and TC of $\$ 523,300.00, \mathbf{N} 51,868.00$ and $\$ 575,168.00$ respectively. The average GM is $\$ 652,700.00$ while the average NFI is $\$ 600,832.00$ with RCI of 1.25 . Since the NFI and BCR are positive, catfish production is a profitable enterprise in the study area. This is in agreement with the reports of Issa et al. (2014) and Olagunju et al. (2007) that catfish production is profitable.

Table 4. Average cost and returns of raising 1000 catfish in Enugu Metropolis

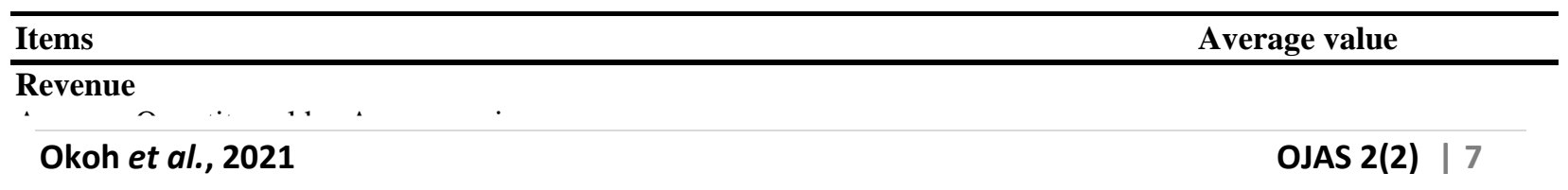


$\begin{array}{ll}\text { Average quantity of catfish sold in } \mathrm{kg} & 1470\end{array}$

$\begin{array}{ll}\text { Average price per kg } & \text { N800 }\end{array}$

$\begin{array}{lr}\text { Total Revenue of market size catfish } & \mathbf{N 1 , 1 7 6 , 0 0 0}\end{array}$

Variable Cost (N)

67 bags of feed @ at an average cost of N5500/bag 368,500

Average 1000 fingerlings @ N30 per fingerlings 30,000

Medication (5\% of feed cost) $\quad 18,425$

Petrol (25 litres for pumping water) $\quad 3625$

$\begin{array}{ll}\text { Transportation } & 16500\end{array}$

$\begin{array}{ll}\text { Utilities } & 9000\end{array}$

$\begin{array}{lr}\text { Contingency } & 17,250\end{array}$

labor $\quad 60,000$

$\begin{array}{lr}\text { Total Variable Cost } & \mathbf{5 2 3 , 3 0 0}\end{array}$

Total depreciated fixed cost $\quad 51,868$

$\begin{array}{lc}\text { Total Cost }(\mathrm{N}) & \mathbf{5 7 5 , 1 6 8}\end{array}$

Source: Field survey, 2018

Gross margin $=$ Total Revenue $(\mathrm{TC})-$ Total Variable Cost $($ TVC $)$

$\mathrm{N} 1,176,000-\mathrm{N} 523,300=\mathrm{N} 652700$

Net Farm Income $=$ Gross Margin - Total Fixed Cost (depreciation)

$\mathrm{N} 652,700-\mathrm{N} 51,868=\mathrm{N} 600,832$.

$\mathrm{RCI}=\mathrm{GM} / \mathrm{TVC}$

$=\mathrm{N} 652700 / 523300=1.25$

\section{CONSTRAINTS MILITATING AGAINST CATFISH PRODUCTION IN ENUGU METROPOLIS}

The analysis of the constraints was done by the means of a 3-point Likert type scale and the result presented in Table 4 below. The respondents indicated the high cost of feeds (mean scale of 2.9) as the most serious constraint to catfish production in the study area. The cost of importation of most commercial feeds into the country and problems associated with importation and distribution could be the main reasons for the hike in feed prices. The second serious problem was the problem of lack of sufficient capital (2.78). Catfish farming is capital intensive and thus requires big capital investment for making more profit. Another serious constraint was poor extension service (2.69). This could be a result of the poor motivation given to the extension agents by the government.

Table 5. Constraints to Catfish Farming in Enugu Metropolis

\begin{tabular}{|c|c|c|}
\hline Constraints & Mean & Standard deviation \\
\hline High cost of feed & $2.9174 *$ & 0.27649 \\
\hline Thonenilohiliter of monliter fonda & 112 & $\cap 1 \cap 7$ \\
\hline Okoh et al., 2021 & & OJAS 2(2) | 8 \\
\hline
\end{tabular}




\begin{tabular}{lll} 
High cost of treatments & 1.31 & 0.560 \\
Poor infrastructure & 1.96 & 0.418 \\
Poor extension advice/service & $2.69^{*}$ & 0.684 \\
Inadequate capitals & $2.78^{*}$ & 0.508 \\
High cost of labor & 1.37 & 0.621 \\
Loss due to stealing & 1.06 & 0.234 \\
Mortality rate & 1.49 & 0.534 \\
\hline
\end{tabular}

Source: Field survey, 2018.

\section{CONCLUSION AND RECOMMENDATION}

The study concludes that catfish production in the study area was dominated by males in their active age who were well educated. Catfish production was very profitable in the study area. The constraints facing the farmers were the high cost of feeds, insufficient capital and poor extension services. These farmers could handle large scale production if capital is made available to them which will also allow them to make more profits.

Based on the findings of this study, the following recommendations were made:

i. Farmers should learn how to compound high quality feeds locally,

ii. Catfish farmers should be encouraged to form and manage functional cooperatives as a way to pool their resources for individual development within the fish farming industry,

iii. Extension agencies should provide fish farmers with qualitative extension services and

iv. Financial institutions and Non-Governmental Organizations should provide credit facilities and grants to catfish farmers.

\section{REFERENCES}

Adefalu, L.L., Adenoye-Adbulwahab, S.A., Bello, O.G., Olurunfemi, O.D., \& Oba, S.A. (2013). Information needs of fish farms in Ilorin metropolis, Kwara State Nigeria. Nigeria Journal of Agriculture and Environment. non.1 $=$ 
Adekoya, B. B. \& Miller, J.W. (2004). Fish cage culture potential in Nigeria- An overview. National Cultures and Agriculture Focus.1(5):10-12.

Afolabi, M. O. (2017). Motivation for involvement in urban catfish farming and sustainable food security in Nigeria. Journal of Education and Practice. 8(11):236-245.

Aihonsu, J.Y. \& Olantingiri, O. A. (2012). Analysis of socio-economic characteristics for policy enactment: The case of artisanal fisherfolks in Ibeju - Lekki Local Government Area of Lagos State, Nigeria. In Refereed Conference Proceedings of the Nigerian Association of Agricultural Economist (NAAE), pp.107-112.

Akinwumi, A. A. (2014). Fish production and balance of payments. Retrieved on $12^{\text {th }}$ June 2021 from http://ww.dailytrust.com.

Amaefula. A. A; Onyekweaku, C.E. \& Asomugha, G.N. (2010). Economic efficiency of fish production in Delta State, Nigeria. The Nigeria Agricultural Journal 41(2):39-44.

Ashley-Dejo, S. S., Omoniyi, I. T., Olaoye, O. J., Fakoya, E. O. \& Adelaja, O. A. (2016). Adoption of improved fish Hatchery technologies by improved fish hatchery managers in Oyo State, Nigeria. Nigerian Journal of Animal Production. 43(2):399 - 411.

CBN (2011): Annual Report and Statement of Accounts. Central Bank of Nigeria (CBN) Publishers, Abuja. Retrieved on $17^{\text {th }}$ March 2021 from http://www.cbn.gov.ng.

Climate-data.org (CDO)(2021). Climate Enugu, Nigeria. Retrieved on 30th May, 2021 from https://en.climatedata.org/africa/nigeria/enugu/enugu-542/.

Department of Geography, University of Nigeria, Nsukka (2015). Map of Enugu Metropolis showing sampled areas.

Enugu State Agricultural Development Program (ENADEP) (2006). Enugu State Agricultural Development program Extension services Report, 2006. Proceedings of the 20th Zonal Research Extension Farmer Input Linkage System (REFILS) workshop, South East Agro-Ecological Zone, held on 21st-25 ${ }^{\text {th }}$ November,2006 Yenegoa, Bayelsa State.

FAO FishStat plus (2012). FAO Fisheries and Aquaculture Statistics and Information Service. Retrieved on $14^{\text {th }}$ June 2021 from http://www.fao.org/fishery/statistics.

Federal Ministry of Agriculture and Rural Development (FMARD) (2016). The Agricultural Promotion Policy (2018-2020) Building on success of the ATA, closing key gaps. Policy and strategy document. Retrieved on $6^{\text {th }}$ April 2021 from http://www.fmardd.gov.ng/agricultural-policy-in-nigeria.

Fregene, T., Inyang, I. \& Awolumote, S. (2011). Operational Attributes of Urban Aquaculture Systems in Ibadan Municipal, Oyo State, Nigeria. In R. Adeyemo (ed), Urban Agriculture, Cities and Climate Change, pp. 173-178.

Ike, P. C. \& Chuks-Okonta,V. A.(2014). Determinants of output and Profitability of aquaculture fish farming in Burutu and Warri South West Local Government Areas of Delta State. Nigeria. Journal of Biology, Agriculture and Healthcare, 4 (28):102-109.

Issa F.O., Abdulazeez, M.O., Kezi, D.M., Dare, J. S. \& Umar, R. (2014). Profitability analysis of small scale catfish farming in Kaduna State, Nigeria. Journal of Agricultural Extension and Rural Development.6 (8): 267 273.

Itam, K.O., Etuk, E.A. \& Ukpong, I.G. (2014). Analysis of resources use efficiency among small scale fish farmers in Cross River State, Nigeria International Journal of Fisheries and Aquaculture, 6 (7): 133-116

National Population Commission (NPC) (2006). National Population Census. Lagos: Federal Republic of Nigeria 
Nigeria Bureau of Statistics (NBS) (2016). Sectorial contributions to gross domestic products. Retrieved on $6^{\text {th }}$ April 2021 from http://www.nigeriasta.gov.ng.

Nkamigbo,D.C., Ovuomarie, O.S., Maduka, J.N. \& Isibor, A.C.(2014). Economic efficiency and profitability of catfish production in Isoko Area of Delta State, Nigeria. Journal of Agriculture and Veterinary Sciences 6 (2): 140-148.

Nwiro, E. (2012). Fish farming, a lucrative business, accessed online 20th February 2021 from http://www.this day line.com/articles/fish - farming-a- lucrative business/119253/.

Ochiaka C.D. \& Obasi C.E. (2019). Analysis of the profitability of catfish production in Enugu East L.G.A of Enugu State, Nigeria .Asian Journal of Advances in Agricultural Research, 10(3): 1-6.

Onyekuru N.A., Ihemezie E.J. \& Chima C.C (2019). Socio-economic and profitability analysis of Catfish production: a case study of Nsukka L.G.A of Enugu State, Nigeria. Journal of Tropical Agriculture, Food, Environment and Extension, 18(2): 51-58.

Olagunju, F.I., Adesiyan, I.O., Ezekiel, A.A. (2007). Economic viability of catfish production in Oyo State, Nigeria Journal of Human Ecology, 21 (2):121-124.

Oluwasola O. \& Ige A.O. (2015). Factors determining the profitability of catfish production in Ibadan Oyo State, Nigeria. Journal of Sustainable Agriculture Research, 4(4), 57-65

Olawunmi, A.T., Dipeolu, A.O. \& Bamiro, O.M (2010). Economic analysis of homestead fish production in Ogun State Nigeria. Journal of Human Ecology, 31(1):13-17.

Ume, S. I., Ebeniro, L. A., Ochiaka, C.D. \& Uche, F. O. (2016). Economic analysis of catfish production in Anambra State, Nigeria. International Journal of Environment, Agriculture and Biotechnology (IJEAB), 1(3): 476-481.

Ugwumba, C.O. A \& Chukwuji C.O. (2010). The economics of catfish production in Anambra State, Nigeria: A profit function approach. Journal of Agriculture and Social Sciences, 1813(2235): 6-4; 105-109.

Yisa , E. S., Adebayo, C.O., Mohammed U.S. \& Anaweta P.U. (2015). Profitability analysis of catfish farming in Suleja local government area of Niger State, Nigeria. Journal of Agriculture and Food Sciences, 13(1):1-16. 